\title{
Factors Affecting Decision Makers Preference of MSMEs in Financing Sources Choice
}

\author{
Ahmed A. M. Al-Afifi \\ School of Business and Management, \\ University of Palestine, \\ ah.afifi@up.edu.ps
}

15 Gaza, Palestine

Received February, 2019; April, 2019

\begin{abstract}
The study examined the choice of the different financing theories for explaining the capital structure source of Micro, Small, and Medium Enterprises (MSMEs) that seeks to raise their capital, through examining the affecting factors on the main capital structure decision. The study used a questionnaire distributed on 220 Palestinian MSMEs in order to examine the financing decisions in these firms according to the main capital structure theories. The study found that in accord with the POT, it was confirmed an approach comprising an initial check on the availability of internal resources, followed by the use of internal capital. Where most of the sample were prefer to depend on personal money rather than to increase their capital through the partners and loans. Therefore, this suggests the need to raise awareness with regard to the concept of capital structure and the other determinations that affect MSMEs' capital financing.
\end{abstract}

Keywords: Capital Structure; Pecking Order Theory; Pot; Trade-Off Theory; Financing Sources, Micro Small and Medium Enterprise; MSME

Type: Research paper

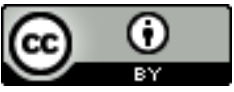

This work is licensed under a Creative Commons Attribution 4.0 International License.

DOI: 10.51325/ijbeg.v2i2.31

\subsection{Background and study problem:}

The private sector in most developing countries consist on micro, small, and medium enterprises (MSMEs), where every year hundreds of thousands of MSMEs lunched in each country. Those people who have a variety background and different cultures are trying to achieve their dreams of owning and operating their own business. Yusoff et.al, (2016) Currently, MSMEs became very important in all countries, where the people believe that the stuff that make life better and easy come from businesses more than it comes from government (Ahmad and Mohamed Zabri, 2015).

Financing decision is the vital decision in financial department in different firms which relay on the optimal capital structure for these firms regardless of the size, industry ... and so on. The goal of any company is to make profits and maximize the wealth of owners, hence, they have to looking continuously for different sources of finance, where the financing process is a renewed process, therefore, it usually selects one or more sources 
depending on available financial sources. Bo Taweel (2014) stated that more investments need more financing.

However, it is often the main cause of business failure is the loss of capital or mismanagement. Similarly, the main reason of cancel pre-configured idea and turn it into reality is the providing capital. Winborg and Landstrom (2001) found that the reason of the limit of growth and development of SMEs is the financial problems (lack of funds); because that many SMEs do not have the ability to access the same types of financing that often available for large companies.

Chen (2004) pointed out that the examinations into the financial practices of MSMEs are still restricted and limited, where the most academic researchers and practical financial analysts focus on big firms and listed companies in stock exchanges that dominate economic life throughout the developed world.

The financing preferences topic, for example, is one of the most difficult restriction that an entrepreneur must overcome to start or raise a business. Many new businesses need at least a small amount of money to get off the ground, but lack of cash should not mean that they have to stop their entrepreneurial dreams. Whether they choose traditional route or try something creative, there are many external and internal sources to finance small business. Financing sources choices is an area that should be understood to enhance general awareness of the financing decisions of MSMEs. Deesomsak et el. (2004) found through examining more than 1,600 small US manufacturing companies that the growth of these companies are to be limited because of the lack of funding. Similarly, Carter and Allen (1997) stated that the availability of financial resources is the major impact on the women-owned businesses growth.

The literature demonstrates that there is a solid relationship between the accessibility of financing and growth of MSMEs, leading to the gap of finance implying that it may be critical barriers that prevent access of an owner-manager equity Hutchinson (2014). Where, in many cases, a lack of funding forces the individuals to give up their ideas and projects. On other hand, investors don't invest in a certain project either because it's not within their interest or because they don't want to take risks. Therefore, the entrepreneurs have to look for creative methods to obtain funds in order to startup their business or raise their capital.

The entrepreneurs have many ideas that will help in improving the economic situation on a personal level, as well as new products and services is working to improve the economic situation in the country. However, the major problem for the owners of these ideas is the inability to get the source of funding, as it is difficult to go to external sources of funding for many reasons, including lack of adequate guarantees for startup of the project. In addition, many financial institutions and banks don't prefer to finance new projects, but prefer to fund working business in order to estimate the future performance of the company through their performance in the past. So, the owner of the idea has to rely on the source of fund that is not costly and suitable for him. Therefore, financing preferences 
and firms' capital structure decisions can be considered a difficult problem for academics, as well as for managers (Esparanca and Gama, 2003).

There are different types of sources of finance for MSMEs that are available for the startups during the different stages of the firm life cycle. Some of it are internal sources such as personal finance, Product presales, friends and family, saving of retirement. While the external sources of financing are like loans, suppliers, crowdfunding, grants, angel investors ... and so on. Therefore, the person has variety of choices of finance for startup his/her business or expanding capital for growth. However, each of these sources have advantages, disadvantages, and obstacles.

So, the problem is which sources is the best for him/her? Myers (1984) pointed out to the important question about how firms choose financing. The suggest answer was "We do not know how firms choose debt, equity ... our (financial) theories don't seem to explain actual financing behavior, and it seems presumptuous to advise firms on optimal capital structure when we are so far from explaining actual decisions ..."

Financial theories don't seem to explain actual financing behavior, it seems presumptuous to advise firms on optimal capital structure when we are so far from explaining actual decisions (Abiodun, 2018, Alareeni, 2018, Alareeni, 2019).

The traditional view of the financing of small, growing firms refers that the small firm when starts, it depends on the owner's personal resources which he is able to put into the business. In the stage of successful and profitable of business, it will use the retained profit as a financing source. As well as, business in this stage has other available sources of finance such as suppliers, trade credit, and commercial banks in the form of loans and overdrafts. In the stage of growing, it has more available of financing sources such as leasing arrangements or issuing shares (Abiola, 2015).

The capital structure refers to liabilities and equity from the balance sheet used to finance the needed assets and resources of the company, which reflecting adopted financial structure for the company's investments. Karadeniz (2009) sees the capital structure as a combination of financing sources that selected to cover the business's needs, as it presents the liabilities in the balance sheet whether debt or ownership.

One of the most important issues that financial management devote their concern is how to choose the appropriate financing mix to finance the company's investments. Kamal (2011) pointed out that the company's management should choose the appropriate financing model that balances the two components of the return on the target investment from the funds borrowed, and the expected risks level from the inability to pay the debt and its interest, moreover, financial leverage has to be taken in consideration. Therefore, the choice is not random. It requires financial management to calculate the cost of the optimal financial structure, because it has a major impact and influence in many decisions of the company. 
Mac and Bhaird (2010) found that most studies that investigated into SMEs' financing choices often seeks explanation the issue in terms of a firm's characteristics (firm size, age, asset value, profitability ... and so on) without considering one important aspect of small business and entrepreneurship, which is the role of the SME owner. Irwin and Scott (2010) for example, developed a conceptual model to clarify the restrictions on increasing bank financing among SMEs in the UK using education, gender and ethnicity of owner as a testing factors. They resulted that the personal characteristics of the owners of the SMEs influence the capability of the increasing business finance.

The literature about the capital structure in the MSMEs and the factors affected have been studied in many times in different aspects around the world. Modigliani and Miller in 1958 are the first who wrote in capital structure theory through examined the firm's value changes though changing its capital structure Modigliani and Miller (1958, 1963) explained that some SME owners may use only one source of finance, and some have two or more different sources representing both formal and informal. Similarly, Watson (2006) pointed out the lower level of external funding of SMEs' is a belonged of personal choice of owner managers which are due to change with owner's characteristics, firm characteristics and external characteristics

One of the most suitable theory for identifying the MSME capital structure is Pecking Order Theory (POT). It is modeling for large corporations. According to Frank and Goyal (2003) stated about the definition of POT concept that the firms depend on hierarchy scale, where they depend for financing preferences firstly on internal finance, and if they have the ability, therefore, the external finance is preferred than equity. However, Huang, and Song (2006) found that small businesses don't have the ability to increase their needed funding through external funds such as financial institutions; therefore, there will face a deficiency between supply and demand for funding. As well as, they pointed out to the importance of identifying the preferences of the SME owners' financing needs.

There a lot of studies that examined the determinations which effect on financing preference among MSMEs such as Hussain et al., (2010), Zhang (2008), Sena et al., (2012), Borgia and Newman (2012) .... And many of other studies use similar indicators of managerial characteristics such as gender, age, education, experience, business age, business ownership .... And so on, are among indicators that are often used in relation to understanding firms' financial practices. This study explains nine factors that may affect financing sources choice in MSMEs. It consists of gender, age, material status, education, major study, experience, religion belief, business age, business size, business type, and startup capital source.

Regarding to gender factors, it plays a significant role in behavior of humans in financing decisions Karadeniz, (2011) pointed out that woman entrepreneurs don't prefer to use an external financing because of a strong desire not to be obligated to others. Similarly, Hussain et al., (2010) found that female entrepreneurs are proven to be equally advantageous with male entrepreneurs when it comes to obtaining business financing. 
Before of them, Hokkanen et al. (1998) highlighted that females depend more on personal savings to finance their business. This is because they are less willing to put up collateral or personal guarantees. Also, Osei-Assibey et al. (2011) pointed out that there is a mixed relationship between gender and financing at different stages of business life. Where, at start-up, female owners are likely to access formal banking credit rather than the male owners.

Regarding to age and professional experience factors, Wu et al., (2008) demonstrated that there is a relationship between business financing and age of business owner's, where they found that the middle age owners have better knowledge of the financial market the young owners and have more chance to get advantages of bank financing. However, Vos et al., (2007) pointed that the older SME's owners are less likely to depend on external financing while younger owners prefer to use external financing. Experience is measured by years' number in the work, where it contributes to access on external credit expanding, where prior experience in the work give more confidence with the access of external financing in SMEs (Nofsinger \& Wang, 2011, Alareeni and Branson, 2013).

Regarding to education qualification and specialization factors, Welmilla et al., (2011) stated that the business owner who has high education and training related to finance increases his knowledge of available sources of finance and their advantages, and disadvantages. Therefore, there is a positive relationship regarding to the firm's usage of leverage. Further, Storey (1994) pointed out that the higher level of education provides give the owners more confidence in with bankers and other external parties when they are applying for facilities.

Regarding to age of the firm factor, it is measured by the number or years since its establishment. As well as, it measures of reputation. Abor \& Biekpe, (2009) found that more working in the field increases the reputation, experience and skills of business owners and then firm will have more ability to increse their capital by external financing. This result is also supported by Quartey (2003), Osei-Assibey, Bokpin, \& Twerefou (2011) \& Hall et al. (2004) who found a significant positive influence of firm age on the ability to access external finance.

Regarding to the firm size factor, the firm size is very important when determining the financing source. There are many measurement scales to determine firm size such as sales amounts, numbers of employees or total asset value. Osei-Assibey, Bokpin, \& Twerefou, (2011) Chen, (2004) stated that POT assumes a negative relationship between firm size and leverage in SMEs. As well as, Gebru, (2009) resulted that SME's owners prefer sole proprietorship and depend on the internal sources of financing before going external sources which confirm the POT where those owners do not like to lose their control over their businesses.

Regarding to the Business Sector factor, Silva \& Carreira (2010) stated that the firms which need less physical assets usually depend on internal finance sources, where they found that service firms that have less physical resources cannot provide collateral when 
they access to external financing, therefore they prefer to use their special money. also, Johnsen \& McMahon (2005) reached to the same result, where they pointed out that the industry differences in financing behavior do the same in SME financing, where service firms is differing from manufacturing or construction in the financing needs and choices.

\subsection{Methodology of study:}

This section describes the sample selection and discusses the development of the hypotheses. It includes two subsections: Sample of study and Hypotheses development.

\subsubsection{Hypotheses Development}

The study used percentages, the average of the answers, relative weights, the value of Ttest, Std. error mean and significant level in order to know the answers respondents according to the requirements of the study.

H1: There are significant relationship between gender and financing source choice preference.

$\mathrm{H} 2$ : There is significant relationship between material status and financing source choice preference.

H3: There is significant relationship between age of owner and financing source choice preference.

H4: There are significant relationship between education and financing source choice preference.

H5: There is significant relationship between MSME owner's experience and financing source choice preference.

H6: There is significant relationship between firm size and financing source choice preference.

H7: There is significant relationship between firm age and financing source choice preference.

H8: There is significant relationship between bus. sector and financing source choice preference.

H9: There is significant relationship between capital source and financing source choice preference.

According to the hypotheses, the financing source preference decisions were act as a dependent variable, whereas, the demographic values act as an independent value, as illustrated in table no ( 1 and 2$)$. Hence, the model of financing source preference decision is as follows:

$$
\begin{gathered}
\mathrm{Y}=\beta 1 \text { Gn. }+\beta 2 \text { Age. } O+\beta 3 \text { M. } S+\beta 4 \text { Edu. }+\beta 5 \text { Maj }+\beta 6 \text { Exp. }+\beta 7 \text { Size }+\beta 8 \text { Age. } \\
F+\beta 9 \text { Sec. }+\beta 10 \text { C.S }
\end{gathered}
$$

\section{Independent variables:}

Table 1: Independent variables

\begin{tabular}{|c|l|c|c|}
\hline Variables & Description & Symbol & Measurement \\
\hline V1 & Gender & Gn. & (1) Male (2) Female \\
\hline
\end{tabular}


The International Journal of Business Ethics and Governance (IJBEG), ), Vol. 2, No. 2, 2019

\begin{tabular}{|c|l|c|l|}
\hline V2 & $\begin{array}{l}\text { Age of the } \\
\text { respondent }\end{array}$ & Age. O & (1) less than 30 years, (2) more than 30 years. \\
\hline V3 & Material status & M.S. & (1) single, (2) Married \\
\hline V4 & $\begin{array}{l}\text { Education of the } \\
\text { owner }\end{array}$ & Edu. & $\begin{array}{l}\text { (1) A/L, (2) Diploma, (3) BSC, } \\
\text { (4) Postgraduate. }\end{array}$ \\
\hline V5 & Major & Maj. & (1) Financial - (2) non-financial- (3) none \\
\hline V6 & $\begin{array}{l}\text { Experience of the } \\
\text { owner }\end{array}$ & Exp. & (1) less than 10 years, (2) more than 10 years. \\
\hline V7 & Size of the firm & Size & No. of employees (1) 1-5, (2) 5-20, (3) 20-99. \\
\hline V8 & Age of the firm & Age. F & $\begin{array}{l}\text { (1) Less than 5 year, (2) 5-10 years, (3) 10-15 } \\
\text { years, and (4) more than 15 years. }\end{array}$ \\
\hline V9 & Business Sector & Sec. & (1) Manufacturing, (2) trade, (3) Services \\
\hline V10 & Capital sources & C.S. & (1) Self-financing, (2) loan, (3) partnership \\
\hline
\end{tabular}

2. Dependent variables: MSME financing choice

Table2 : Dependent variables: MSME financing choice

\begin{tabular}{|c|c|}
\hline Original Value & Dependent Variable Encoding \\
\hline External financing source & 0 \\
\hline Own Savings / Retained & 1 \\
\hline
\end{tabular}

\subsubsection{Population and sample of study:}

The Palestinian Center Bureau of Statistics (PCBS) and Chambers of Commerce classified MSMEs according to number of employees including the owner as the following table:

Table3 : MSME classification

\begin{tabular}{|c|c|c|c|}
\hline Micro & Small & Medium & Large \\
\hline $\begin{array}{c}\text { Less than 5 } \\
\text { employees }\end{array}$ & $5-19$ employees & $\begin{array}{c}20-99 \\
\text { employees }\end{array}$ & $\begin{array}{c}\text { More than 100 } \\
\text { employees }\end{array}$ \\
\hline
\end{tabular}

The study's target population was consisted of MSMEs' owners in Gaza, Palestine from 1 to 99 employee size.

The sample is consisted of 250 MSMEs' owners. It was used a random sampling technique in order to ensure that the entire relevant target group are represented. The target sample was 250 respondents, with 220 eligible responses used as a final sample. The table (3) explore the sample characteristics.

\subsubsection{Data collecting sources:}

the study depended for Data collecting on primary and secondary sources. Secondary sources were included books, journals, and specialized publications on the field of study, whereas primary sources were collected by a questionnaire to study sample who represented as owners and decision makers of MSMEs in Gaza strip in order to study the preference choices of financing sources. 
Study used in the questionnaire design open-ended and closed-questions in order to measure the preferences choices of financing sources. The study used standardization criteria to answering questions. Then it used SPSS statistical program to analys the study hypotheses.

\subsubsection{The validity and reliability of the questionnaire:}

The study examined the validity and reliability of the questionnaire by pretesting by a pilot test, and other statistical methods. The questionnaires were piloted by given to 5 scholarly specialists in MSME field and statistical analysis as well as to 5 MSME owners, and were then refined after each collection.

As well as, the study was confirmed of the questionnaire's validity and reliability using SPSS, where it was used 10 cases as the minimum number of cases per independent variable. through the guideline provided by Hosmer and Lemeshow, authors of Applied Logistic Regression, the study used a preferred ratio of 20 to 1 . In this analysis, there are 220 valid cases Vs. 6 independent variables. The ratio of cases to independent variables is 36 to 1 , which satisfies the minimum requirement.

\section{Data statistical analysis and results:}

\subsection{Descriptive Statistics:}

In order to examine the effect of demographic variables on the financing sources choices preferences, it was identified the characteristics of the study sample, the study analyzed data from the first part of the questionnaire, which constitute demographic data of the respondents. The analysis of the results as illustrated in Table (4) as follows:

Table4 : sample's characteristics

\begin{tabular}{|c|c|c|c|}
\hline \multicolumn{2}{|c|}{ Variable } & \multicolumn{2}{c|}{ Frequency } \\
\hline \multirow{2}{*}{ Sex } & & No. & Percent $\%$ \\
\hline \multirow{2}{*}{ Material status. } & Male & 194 & 88.18 \\
\cline { 2 - 4 } & female & 26 & 11.87 \\
\cline { 2 - 4 } Age. & Single & 82 & 37.27 \\
\hline \multirow{2}{*}{ Educational level. } & married & 138 & 62.73 \\
\cline { 2 - 4 } & Under 30 years & 70 & 31.82 \\
\cline { 2 - 4 } & Over 30 years & 150 & 68.18 \\
\hline \multirow{2}{*}{ Major } & High school & 28 & 12.73 \\
\hline \multirow{2}{*}{ Financial experience. } & university & 192 & 87.27 \\
\cline { 2 - 4 } & Financial & 71 & 32.27 \\
\cline { 2 - 4 } & Not financial & 149 & 67.73 \\
\hline
\end{tabular}


The International Journal of Business Ethics and Governance (IJBEG), ), Vol. 2, No. 2, 2019

\begin{tabular}{|c|c|c|c|}
\hline \multirow{2}{*}{ Business size } & $1-5$ employees & 176 & 80.00 \\
\cline { 2 - 4 } & $5-20$ employees & 44 & 20.00 \\
\hline \multirow{2}{*}{ Life of business. } & Under 10 years & 141 & 64.09 \\
\cline { 2 - 4 } & Over 10 years & 79 & 35.91 \\
\hline \multirow{2}{*}{ Sector type. } & Trade & 138 & 62.72 \\
\cline { 2 - 4 } & Services & 56 & 25.45 \\
\cline { 2 - 4 } & industry & 26 & 11.81 \\
\hline
\end{tabular}

According to sample descriptive characteristics analysis, it was found that most of sample was from the male with $88 \%$ which reflect the male culture in Gaza society that support male culture.

According to Material status, it was found that around $63 \%$ of sample were married. this refers to the existence of significant financial experience resulted from married life

Regarding to the average age of respondents' sample. the analysis found that most of respondents of young people who over the age of 30 years, where about $68 \%$ of respondents age were more than 30 years. Thus, the study sample included all ages, where they have the experience and ability to make financing decision.

Education plays a major role in raising the financial awareness level of the financing decision maker and thus affect the choice of the optimal financing source in order to achieve profits. Regarding the level of education and professional experience. Most of the sample respondents are with a college education, where it was found that more than $87 \%$ of respondents have a first degree (BA) or higher grades (MS or $\mathrm{PhD})$. However, around $67 \%$ of the business owners or financing decision makers studied non-financial specialization, which refers to the weakness of ability to make financing decisions based on sound scientific.

According to the professional expertise. the analysis demonstrated that most respondents have a professional experience, where it increases their confidence in these decisions, based on their experience in practice. it was found that the professional experience they can apply scientific concepts to make sound financial decisions which will help to choose the best source to finance their operations.

Regarding to MSMEs characteristics, it turns out that most of these companies are commercial and services companies, where sample analysis showed that about $88 \%$ of MSMEs type are commercial or services firms, such as groceries, small restaurants, small travel's offices and advisory and training services. Most of these firms do not require a large capital. Therefore, many of the companies' owners depend on family or personal finance for the establishment of these companies,

As well as, it was found that $77 \%$ of the firms have been established through selffinancing (family or personal savings). Business owners in the Gaza Strip do not usual 
depend on bank loans to set up and finance their businesses due to the difficulty in obtaining loans and a lot of guarantees required to approve the granting of the loan.

According to life of business, note that small projects that old less than 10 years is about $64 \%$ of the sample, the reason for this is that these businesses were in one period where economic conditions have not changed and the country's politics.

\subsection{Model estimation results:}

Since the problem states that there is a relationship without requesting the best predictors, study used Binary Logistic Regression Tests. Where, the simultaneous method in which all independents are included at the same time. The study used 0.05 as alpha for the Binary Logistic Regression.

\subsubsection{Independent and dependent variables relationship:}

Table 5: Omnibus Tests of Model Coefficients

Omnibus Tests of Model Coefficients

\begin{tabular}{|l|l|r|r|r|}
\hline \multicolumn{2}{|c|}{} & Chi-square & \multicolumn{1}{c|}{ df } & \multicolumn{1}{c|}{ Sig. } \\
\hline \multirow{3}{*}{ Step 1 } & Step & 91.891 & 6 & .000 \\
\cline { 2 - 5 } & Block & 91.891 & 6 & .000 \\
\cline { 2 - 5 } & Model & 91.891 & 6 & .000 \\
\hline
\end{tabular}

The relationship between the dependent variable and combination of independent variables on the statistical significance of the chi-square model at step 1 after the including of independent variables to the analysis.

In this analysis, the probability of the model chi-square $(91.891)$ was $<0.001$, less than or equal to the level of significance of 0.05 . we reject the null hypothesis that there is no difference between the model with only a constant and the model with independent variables was rejected. The existence of a relationship between the independent variables and the dependent variable was supported.

\subsubsection{The accuracy of the model}

Table 6 : The accuracy of the model

Classification Table ${ }^{\mathrm{a}}$

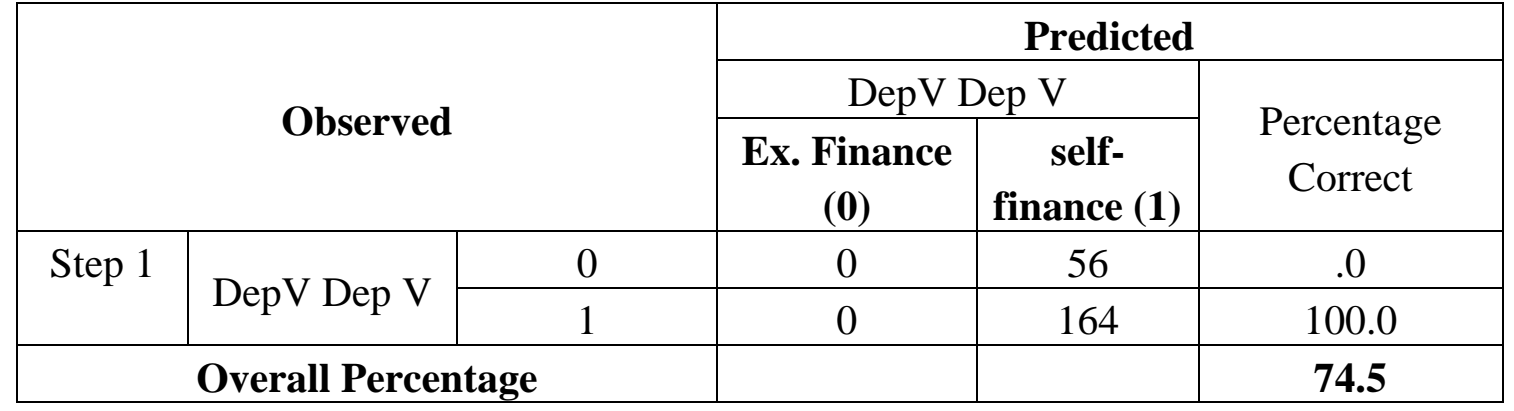


a. The cut value is .500

The accuracy rate in table no. (6) which was computed by SPSS was $74.5 \%$ where it was greater than or equal with the chance accuracy criteria of 0.614

$(56 / 220) *(56 / 220)+(164 / 220) *(164 / 220)=0.614 \ldots$. Hence, the criteria for classification accuracy is satisfied.

\subsubsection{Variables in the equation}

Through analyzing the demographic factors which illustrated in table no (7).

Table 7: Variables in the Equation

Variables in the Equation

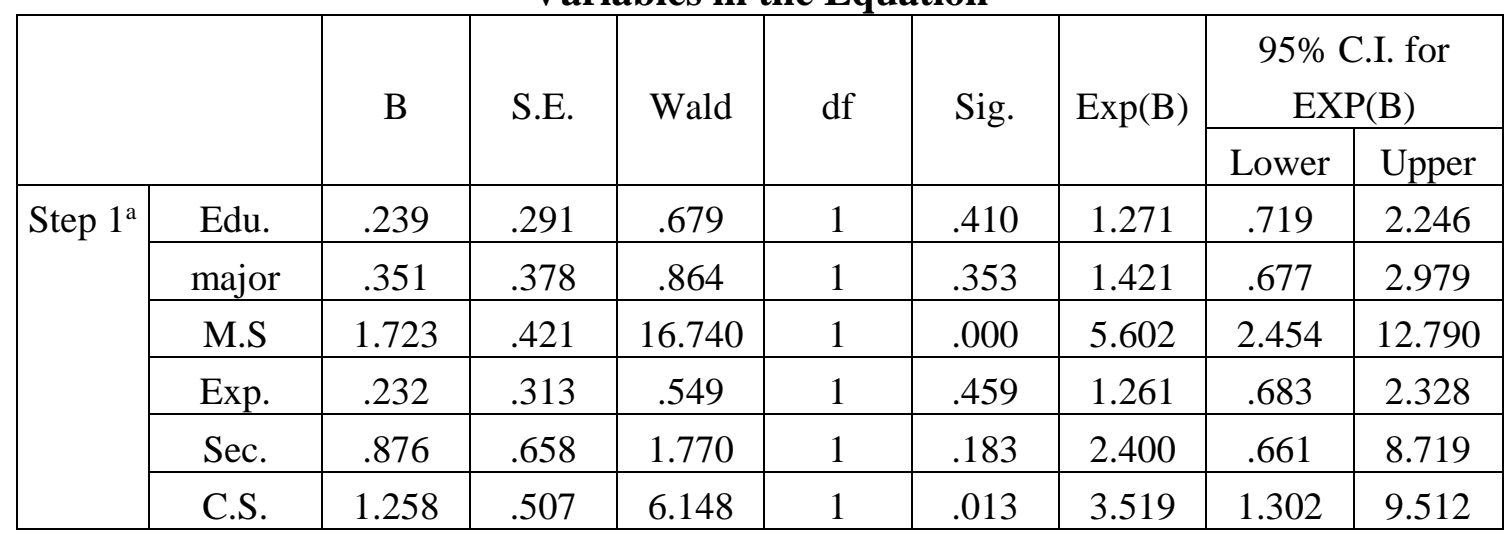

a. Variable(s) entered on step 1: Edu, major, M.S, exp, Sec., C.S.

1. the higher educational level Variable. It has a positive coefficient 1.271. This explains that when other variables get constant, If the person has more education, this means the ability to make sound decision for financing source increased in odds by approximately one and quarter times Dev variable .while if he does not have this qualification, it means that will not add any degree in the case of the stability of the other variables.

2. Major variable. It has positive coefficient by 1.421 . This explains that if a person has a financial major, this means the level of making sound decision for financing source increase in odds by approximately one and 0.4-times Dev variable.

3. Financial experience variable. It has a positive coefficient by 1.261 . This means that if a person has a long financial experience age, this means the level of making sound decision for financing source increase in odds by approximately 1,.261 degree. Otherwise, will not add any degree in the case of the stability of the other variables.

4. Material status variable. It has a positive coefficient by 5.602. This means that if a person is married, this means the level of making sound decision for financing source 
increase odds by approximately 5.6 times Dev variable. Otherwise, will not add any degree in the case of the stability of the other variables.

5. business sector variable. It has a positive coefficient by 2.4 . This means that if business type was trade or industries, the decision maker will be able to make right financial decision, therefore the level of making sound decision for financing source increase by 2.4 degrees. Otherwise, will not add any degree in the case of the stability of the other variables

6. Capital sources variable. It has a positive coefficient by 3.519 . This means that if the source of capital is personal funding or family funding, this means the level of making sound decision for financing source increase by 3.519 degrees. Otherwise, will not add any degree in the case of the stability of the other variables.

Hence, the form of the first model as follows:

Y = 1.723 M. S + 0.239 Edu. + 0.351 Maj. + 0.232 Exp. + 0.876 Sec. + 1.258 C.S.

\section{Conclusions and recommendations:}

According to analysis and discussion of the theoretical and practical sections, the study found the following results:

- There is a positive effect of the factors (education, specialized, material status, professional experience, sector type, and source of capital). While the other nominated factors are not effect on the financing sources preference decision.

- Women MSME owners are more conformances to POT than men. The result was due to many factors such as male culture in the works, preference for men in the high level of the works ... and so on.

- Married person are more conformances to POT than single This is due to the family obligations.

- Small and Micro firms are the most uses of Pecking Order Theory (POT).

- MSME owners who do not have adequate experience follow the Pecking Order Theory (POT) when choose their capital sources.

- The financial illiterates of MSME owners and who with less educated are more comfortable with Pecking Order Theory (POT).

Regarding to conclusion, MSMEs' owners are more conformance with the internal sources of financing and don't depend on the external financing sources. therefore, the study recommends MSMEs' owners and decisions makers to:

- Help MSMEs' owners to be able to retain sufficient profits in their business through providing a suitable environment.

- Encouraging banks to provide credit supports with low cost credit, credit guarantee and equity investment schemes that help MSMEs.

- promotion the financial awareness among entrepreneurs through workshops, interviews about financial decision topics.

- enhancing the role of women as an effective entrepreneur like a man. 
- examination of the other influencing independent factors that may have affect capital structure and financial performance of MSMEs.

\section{References}

Abor, J., \& Biekpe, N. (2007). How do we explain the capital structure of SMEs in subSaharan Africa?. Economics Studies, 36, 83-97. https://doi.org/10.1108/01443580910923812

Ahmad, K., \& Zabri, S. M. (2015). Factors explaining the use of management accounting practices in Malaysian medium-sized firms. Journal of Small Business and Enterprise Development, 22( 4), 762-781. https://doi.org/10.1108/JSBED-04-2012$\underline{0057}$

Alareeni, B. (2018). Does corporate governance influence earnings management in listed companies in Bahrain Bourse?. Journal of Asia Business Studies, 12(4), 551-570. https://doi.org/10.1108/JABS-06-2017-0082

Alareeni, B. (2018). The impact of firm-specific characteristics on earnings management: evidence from GCC countries. International Journal of Managerial and Financial Accounting, 10(2), 85-104. https://doi.org/10.1504/IJMFA.2018.10012808

Alareeni, B. (2018). Does corporate governance influence earnings management in listed companies in Bahrain Bourse?. Journal of Asia Business Studies, 12(4), 551-570. https://doi.org/10.1108/JABS-06-2017-0082

Alareeni, B., \& Branson, J. (2013). Predicting listed companies' failure in Jordan using Altman models: a case study. International Journal of Business and Management, 8(1), 113-126. https://doi.org/10.5539/ijbm.v8n1p113

Alareeni, B.A. (2019). The associations between audit firm attributes and audit qualityspecific indicators: A meta-analysis, Managerial Auditing Journal, 34(1), 6-43. https://doi.org/10.1108/MAJ-05-2017-1559

Asif, A., Rasool, W., \& Kamal, Y. (2011). Impact of financial leverage on dividend policy: Empirical evidence from Karachi Stock Exchange-listed companies. African Journal of Business Management, 5(4), 1312-1324.

Babajide Abiola A et.al., (2015). Bank consolidation and small business financing in Nigeria, International Journal of Advances in Management and Economics, 4(2), $37-47$

Bo Taweel; A., (2014). The effect of capital structure on financial performance of economic firm. Mohammed Khudair University, Master thesis, Algeria.

Chen, J. J. (2004). Determinants of capital structure of Chinese-listed companies. Journal of Business research,57(12), 1341-1351. https://doi.org/10.1016/S0148$\underline{\text { 2963(03)00070-5 }}$

Deesomsak, R., Paudyal, K., \& Pescetto, G. (2004). The determinants of capital structure: evidence from the Asia Pacific region. Journal of Multinational Financial Management, 14(4-5), 387-405. https://doi.org/10.1016/j.mulfin.2004.03.001

Eniola, A. A., Dada, D. A., \& Alo, E. A. (2018). Entrepreneurial peculiarity and financing sources. International Journal of Research,7(1), 59-73. https://doi.org/10.5861/ijrsm.2018.3004

Esparanca, J. P. and Gama, A. P. M. (2003). Corporate debt policy of small firms: an empirical re-examination. Journal of Small Business and Enterprise Development, 0(1), pp. 62-80. https://doi.org/10.1108/14626000310461213 
Frank, M. Z., \& Goyal, V. K. (2003). Testing the pecking order theory of capital structure. Journal of financial economics, 67(2), 217-248. https://doi.org/10.1016/S0304-405X(02)00252-0

Hall, G. C., Hutchinson, P. J., \& Michaelas, N. (2004). Determinants of the capital structures of European SMEs. Journal of Business Finance \& Accounting, 31(5-6), 711-728. https://doi.org/10.1111/j.0306-686X.2004.00554.x

Hokkanen, P., Lumme, A., \& Autio, E. (1998). Gender-based non-differences in bank shopping and credit terms. Frontiers of Entrepreneurship Research.

Hussain, J. G., Scott, J. M., Harrison, R. T. and Cindy Millman, C. (2010). Enter the dragoness": firm growth, finance, guanxi, and gender in China. Gender in Management: An International Journal, 25(2), 137 - 156. https://doi.org/10.1108/17542411011026302

Irwin, D. and Scott, J. M. (2010). Barriers faced by SMEs in raising bank finance. International Journal of Entrepreneurial Behaviour \& Research, 16(3), 245-259. https://doi.org/10.1108/13552551011042816

Johnsen, P. C., \& McMahon, R. G. (2005). Cross-industry differences in SME financing behaviour: An Australian perspective. Journal of Small Business and Enterprise Development, 12(2), 160-177. https://doi.org/10.1108/14626000510594584

Karadeniz, E., Kandir, S.Y., Balcilar, M. and Onal, Y.B., (2009). Determinants of capital structure: evidence from Turkish lodging companies, International Journal of Contemporary Hospitality Management, 21(5), 594-609. https://doi.org/10.1108/09596110910967827

Karadeniz, E., Serkan, Y., \& Iskenderoglu, O. (2011). Firm size and capital structure decisions: Evidence from Turkish lodging companies. International Journal of Economics and Financial Issues, 1(1), 1.

Kuruppu, G., \& Azeez, A. (2016). Financing preferences of small and medium enterprise owners of Sri Lanka: Does pecking order theory hold?. Journal of Business \& Economic Policy, 3(2), 79-92.

Mac an Bhaird, C. (2010). The Modigliani-Miller proposition after fifty years and its relation to entrepreneurial finance. Strategic Change, 19(1-2), 9-28. https://doi.org/10.1002/jsc.855

Modigliani, F., \& Miller, M. H. (1958). The cost of capital, corporation finance and the theory of investment. The American economic review, 48(3), 261-297.

Modigliani, F., \& Miller, M. H. (1963). Corporate income taxes and the cost of capital: a correction. The American economic review, 53(3), 433-443.

Nofsinger, J. R., \& Wang, W. (2011). Determinants of start-up firm external financing worldwide. Journal of Banking \& Finance, 35(9), 2282-2294. https://doi.org/10.1016/j.jbankfin.2011.01.024

Osei-Assibey, E., Bokpin, G. A., \& Twerefou, D. K. (2011). Microenterprise financing preference (Testing $\mathrm{POH}$ within the context of Ghana's rural financial market). Economic Studies, 39, 84-105. https://doi.org/10.1108/01443581211192125

Quartey, P. (2003). Financing small and medium enterprises (SMEs) in Ghana. Journal of African Business, 4(1), 37-55. https://doi.org/10.1300/J156v04n01_03

Sara, C., \& Peter, R. (1998). The financing of male-and female-owned businesses. Entrepreneurship \& Regional Development, 10(3), 225-242. https://doi.org/10.1080/08985629800000013

Šarlija, N., \& Harc, M. (2012). The impact of liquidity on the capital structure: a case study of Croatian firms. Business Systems Research Journal,3(1), 30-36. https://doi.org/10.2478/v10305-012-0005-1 
Silva, F., \& Carreira, C. (2010). Financial constraints: Are there differences between manufacturing and services? (No. 2010-16). GEMF, Faculty of Economics, University of Coimbra.

Storey, D. J. (1994). Understanding the small business sector. Routledge, London.

Vos, E., Yeh, A. J-Y., Carter, S. and Tagg, S. (2007). The happy story of small business financing. Journal of Banking and Finance, 31(9), 2648-2672. https://doi.org/10.1016/j.jbankfin.2006.09.011

Welmilla, I., Weerakkody, W.A.S., \& Ediriweera, A. N. (2011). The impact of demographic factors of entrepreneurs on development of SME in tourism industry in Sri Lanka. Proceedings of the ICBI. Colombo: Faculty of Commerce and Management Studies.

$\mathrm{Wu}$, J. Song, J. and Zeng, C. (2008). An empirical evidence of small business financing in China. Management Research News, 31(12), 959-975. https://doi.org/10.1108/01409170810920666

Yusoff, W. F. W, Gafar, M, Mohamed Zabri, S, and Omar, S. S. (2016). An analysis of entrepreneurial ecosystem among Small Medium Industries (SMEs) in Malaysia: A proposed model. International Business Management, 10(17), 3762-3769.

Zhang, G. B. (2008). The choice of formal or informal finance: Evidence from Chengdu, China. China Economic Review, 19(4), 659-678. https://doi.org/10.1016/j.chieco.2008.09.001 